\title{
Kebakaran Hutan Terhadap Perekonomian Masyarakat Petani Sereh Wangi di Kecamatan Blangkejeren, Kabupaten Gayo Lues
}

\author{
(Forest Fires on The Economy of The Lemongrass Farming Community in \\ Blangkejeren District, Gayo Lues Regency)
}

\author{
Silawati $^{1}$, Martunis ${ }^{1}$, Iqbar ${ }^{1 *}$ \\ ${ }^{1}$ Program Studi Kehutanan PSDKU Unsyiah Gayo Lues, Fakultas Pertanian \\ Universitas Syiah Kuala \\ *Corresponding author: iqbar@unsyiah.ac.id
}

\begin{abstract}
Abstrak. Kebakaran hutan merupakan salah satu penyebab utama kerusakan hutan yang dapat mengganggu dan mengancam kelestarian sumberdaya hutan kebakaran hutan dan lahan yang tidak rerkendali akan menyebabkan kerugian lingkungan, baik dari aspek sosial, ekonomi maupun ekologi. Analisis Dampak Kebakaran Hutan Terhadap Perekonomian Masyrakat Petani Sere Wangi Di Kecamatan Blangkejeren Kab Gayo Lues. Merupakan salah satu hutan di blangkejeren Kab Gayo Lues yang terjadi kebakaran hutan. Kebakaran hutan terluas di kawasan Blangkejeren Kab Gayo Lues pada tahun 2018 berada di paya jergang yang terjadi kebun masyarakat. Kebakaran hutan di blangkejeren menimbulkan kerugian terhadap masyarakat dan pengelola. Mengingat pentingnya peran tanaman dalam hutan pengelola dan perlindungan sumberdaya hutan, maka di perlukan kajian tentang Pola waktu dan nilai kerugian kebakaran hutan di blangkejeren .Metode analisis data yang digunakan dalam penelitian ini terdiri dari metode regresi logistik, metode loss of earning, metode benefit transfer, dan analisis deskeriptif. Hasil penelitia menunjukan pola waktu kebakaran hutan di blangkejeren kab Gayo Lues pada bulan Agustus, Sebtember dan Oktober. Faktor ini penyebab terjadinya kebakaran hutan disebabkan oleh faktor manusia baik yang disengaja ataupun yang tidak disengaja . kerugianya langsung akibat kerusakan lahan dan lingkungan serta hilangnya sumberdaya hutan.
\end{abstract}

Kata Kunci: Hutan, Kebakaran, Pendapatan dan kerugian.

\begin{abstract}
Forest fires are one of the main causes of forest destruction which can disrupt and threaten the sustainability of forest resources and uncontrolled land and forest fires will cause environmental losses, both from social, economic and ecological aspects. Analysis of the Impact of Forest Fires on the Economy of the Community of Sere Wangi Farmers in Blangkejeren District, Gayo Lues Regency. It is one of the forests in the Blangkejeren of Gayo Lues Regency where a forest fire has occurred. The widest forest fires in the Blangkejeren area of Gayo Lues Regency in 2018 were in the middle of an area that occurred in community gardens. Forest fires in Blangkejeren cause loss to the community and managers. Given the important role of plants in forest management and protection of forest resources, it is necessary to study the time pattern and value of forest fire losses in Blangkejeren. Data analysis methods used in this study consist of logistic regression methods, loss of earning methods, benefit transfer methods, and descriptive analysis. The results of the research show the time pattern of forest fires in Blangkejeren, Gayo Lues Regency in August, September and October. This factor causes forest fires to be caused by human factors, whether intentional or unintentional. the loss are direct due to land and environmental loss and loss of forest resources.
\end{abstract}

Keywords: Forest, of income and losses 


\section{PENDAHULUAN}

Kebakaran hutan merupakan kejadian dimana api melalap bahan bervegetasi yang terjadi di dalam kawasan hutan yang menjalar secara bebas dan tidak terkendali. Kebakaran hutan juga merupakan fenomena yang sering terjadi di Indonesia yang menjadi perhatian lokal dan global. Kabupaten Gayo Lues $86.13 \%$ atau 478,053 ha merupakan tutupan hutan, berupa Taman Nasional Gunung Leuser (TNGL) 36.32\%, hutan lindung $39.81 \%$, hutan produksi terbatas $4.51 \%$, hutan produksi $5.39 \%$ dan $0.12 \%$ hutan dengan luasan seperti itu Kabupaten Gayo Lues hanya memiliki 152 orang Polisi Hutan (Polhut). Rasio Polhut terhadap luas kawasan hutan adalah 1:3,145 artinya seorang polhut harus mengawasi 3,145 ha. Sejauh ini pembangunan di sektor kehutanan fungsi hutan, rehabilitasi hutan dan lahan.

Dampak ekologi akan mengganggu proses ekologi antara lain suksesi alami, produksi bahan organik dan proses dekomposisi, siklus unsur hara, siklus hidrologi dan pembentukan tanah. Selain itu mengganggu fungsi hutan sebagai pengatur iklim dan penyerap karbon. Dampak ekologi lainnya adalah hilangnya keberagaman hayati dan ekosistemnya. Kebakaran juga melepaskan banyak emisi karbon dan gas rumah kaca ke atmosfer yang memperburuk perubahan iklim (Rasyid, 2014).

Sereh wangi dalam proses penanamannya hingga berproduksi tidak rentan terhadap serangan hama dan dapat ditanaman disembarang jenis lahan termasuk lahan kritis. Namun satu-satunya masalah dari pertanian sereh wangi ini adalah kebakaran hutan. Tanaman ini juga sangat mudah terbakar terutama pada saat musim kemarau. Kebakaran hutan selain berdampak merugikan lingkungan juga memiliki potensi menguntungkan misalnya dapat meningkatkan kesuburan tanah, Oleh karena itu diperlukan penelitian untuk mengkaji sampai sejauh mana dampak kebakaran hutan dapat dirasakan menguntungkan dan seberapa besar jika dibandingkan dengan dampaknya yang merugikan.

\section{METODE PENELITIAN}

\section{Tempat dan Waktu Penelitian}

Penelitian dilakukan pada tiga Desa yaitu Desa Agusen, Desa Penggalangan dan Desa Sere Kecamatan Blangkejeren Kabupaten Gayo Lues. Penelitian ini berlangsung selama satu bulan pada bulan Januari sampai dengan Febuari 2019.

\section{Objek dan Ruang Lingkup Penelitian}

Objek yang digunakan dalam penelitian ini adalah petani sereh wangi yang merupakan masyarakat Desa Agusen, Desa Penggalangan, dan Desa Sere Kecamatan Blangkejeren Kabupaten Gayo Lues.

\section{Teknik dan pengambilan sampel}

Sampel dalam penelitian ini adalah petani yang memiliki lahan sereh wangi yang terdapat di Desa Agusen, Desa Pengalangan dan Desa Sere, Kecematan Blangkejeren, Kabupaten Gayo Luas. Metode penelitian yang digunakan adalah survei. Survei dilakukan terhadap petani sereh wangi 
yang dipilih secara acak (random sampling) yang berjumlah 22 orang responden.

\section{Analisis Data}

Analisis data dalam penelitian ini mengunakan teknik analisis deskriptif, data diperoleh dari hasil pengamatan di lapangan melalui wawancara, observasi, dan kuesioner. Kemudian data tersebut dianalisis secara kuantiatif yaitu untuk mengetahui dan menganalisis data yang terkumpul dari hasil kuesioner, wawancara, observasi dan studi pustaka. Data yang diambil dan yang sudah dikumpul dari hasil kuesioner dinyatakan dalam bentuk gambar, tabel dan grafik berupa karakteristik responden, aspek pengeluaran dan aspek pendapatan.

\section{HASIL DAN PEMBAHASAN}

\section{Karakteristik Responden Berdasarkan Jenis Kelamin}

Jenis kelamin adalah salah satu variabel yang diasumsikan mempunyai pengaruh besar terhadap pendapatan petani Sereh wangi. Jenis kelamin seseorang akan memberi pengaruh dalam penguasaan pengetahuan profesi tertentu seperti petani Sereh wangi. Meskipun tidak selamanya responden berdasarkan jenis kelamin dapat dijadikan sebagai acuan. Distribusi responden berdasarkan jenis kelamin responden dapat dilihat pada gambar karakteristik responden di bawah ini.

\section{Perekonomian Petani Sereh Wangi di Desa Agusen Sebelum Kebakaran hutan.}

Berdasarkan hasil pendapatan pada masyarakat Desa Agusen yang menyatakan bahwa pendapatan dan pengeluaran rata-rata masyrakat dari perkebunan sereh wangi. Berdasarkan tabel 4.2 di atas dapat dilihat bahwa secara keseluruhan, Status kepemilikan lahan sereh wangi di Desa Agusen adalah milik sendiri dengan luas lahan berisar antara 0,4-0,6 ha. dengan jangka waktu kepemilikan rata-rata 11,8 tahun dan rata produksi minyak sereh wangi persetiap kali panen petani sereh wangi persetiap panen adalah 2,4 kg. Dari jumlah produksi setiap panen petani sereh wangi di Desa Agusen mendapatkan pendapatan sebesar rata-rata Rp19.600.000 dengan pengeluaran 2.400.000 dan laba yang di peroleh permasa panen adalah sebesar 17.200.000.

\section{Perekonomian Masyrakat Petani Sereh Wangi (Sesudah Kebakaran Hutan).}

Berdasarkan hasil wawancara dengan masyarakat Desa Agusen, Desa Penggalangan dan Dasa Sereh menyatakan bahwa pendapatan dan penerimaan rata-rata masyarakat bersumbar dari perkebunan Sereh wangi. Berdasarkan tabel di atas dapat dilihat bahwa secara keseluruhan, kepemilikan lahan Sereh wangi di Desa Agusen adalah milik sendiri dengan dengan luas lahan berkisar antara 0,1-0,2 ha dengan jangka waktu kepemilikan rata-rata 12 tahun. Berdasarkan tabel di atas dapat dilihat bahwa dari kelima responden menunjukan desa Agusen dari Kepemilikan lahan Sereh wangi pertahun dengan rata-rata 12 pertahun memiliki hasil peroduksi permasa panen dengan rata-rata $2,4 \mathrm{~kg}$ dengan pendapatan/ masa penen sebesar Rp 7.680.000 dengan pengeluaran sebesar Rp 960.000 dan laba yang diperoleh permasa panen adalah seberar Rp Rp 6.720.000. sejalan dengan penelitian (Denis, 1999). Kebakaran hutan di Indonesia merupakan 
suatu kejadian yang terus berulang selama kurun waktu 20 tahun terakhir ini, sejak kebakaran hutan besar tahun 1982/1983 di Kalimantan Timur yang menghabiskan 3.5 juta ha hutan (KMNLH dan UNDP, 1998), intensitas kebakaran hutan makin sering terjadi kebakaran sebarannya makin meluas. tercatat kebakaran besar di Indonesia terjadi pada tahun 1987, 1991, 1994, dan 1997/1998.

Tabel 4.8 Jumlah total pendapatan responden sesudah kebakaran hutan

\begin{tabular}{ccc}
\hline Desa & Pendapatan/masa panen & Persentase\% \\
\hline Agusen & Rp 38.400.000 & $60 \%$ \\
Penggalangan & Rp 25.00 .000 & $39 \%$ \\
Sereh & Rp 1.811 .000 & $0,02 \%$ \\
Jumlah Total & Rp 63.601.811 & $100 \%$ \\
\hline
\end{tabular}

Berdasarkan tabel di atas dapat dilihat bahwa jumlah pendapatan masyarakat sesudah terjadinya kebakaran hutan yang terdapat ditiga desa yaitu desa Agusen Rp 38.400.000 atau sekitar (60\%), sedangkan pendapatan/ masa panen dari desa Penggalangan sejumlah Rp 25.200.000 atau sebanyak (30\%) serta pendapatan / masa panen dari Desa Sere berjumlah Rp 1.811 .000 atau sebesar $0,02 \%$. Jadi total secara keseluruhan dari tiga desa tersebut adalah berjumlah sebesar $\mathrm{Rp}$ 63.601.811 pendapatan responden dari Sereh Wangi. Sejalan dengan penelitian (Purwoko, 2015) menyatakan bahwa kontribusi yang disumbangkan dari hasil hutan sangat besar. Kondisi ini mengindikasikan bahwa ketergantungan masyarakat terhadap keberadaan hutan sebagai sumber pendapatan keluarga sangat tinggi.

Tabel 4.9 Selisih pendapatan responden sebelum dan setelah kebakaran hutan

\begin{tabular}{cccc}
\hline Desa & Sebelum Kebakaran & Sesudah Kebakaran & Selisih \\
\hline Agusen & Rp 98.400 .000 & Rp38.400.000 & Rp -6,000 \\
Penggalangan & Rp 43.200.000 & Rp25.200.000 & Rp18.000.000 \\
Sere & Rp 60.480.000 & Rp1.811.000 & Rp58.669.200 \\
Total & Rp202.080.000 & Rp65.410.800 & Rp67.069.200 \\
\hline
\end{tabular}

Berdasarkan tabel 4.9 diatas menjelaskan bahwa selisih dari kebakaran hutan didesa Agusen, pengalangan dan Sereh Sebelum kebakaran hutan dengan total Rp. 202.080.000 sedangangkan Sesudah kebakaran hutan dengan total Rp. 65.410.800 kebakaran hutan dengan selisih dengan total Rp 67.069.200 setelah dari data tersebut dapat diketahui bahwa pendapatan dari kebakaran hutan Sereh wangi sebelum memberikan hasil yang lebih besar dibandingkan dengan pendapatan Sesudah kebakaran hutan. Dari data tersebut dapat diketahui bahwa pendapatan dari kegiatan pembakaran tanaman sereh wangi (sebelum kebakaran sereh) memberikan hasil yang lebih besar dibandingkan dengan pendapatan dari 
pemanfaatan tanaman (sesudah kebakaran). Hal ini memberikan keuntungan cukup tinggi bagi responden. Penelitian kerugian ekonomi bersih dari kebakaran, yang merupakan selisih antara biaya dan manfaat, kemungkinan besar lebih rendah daripada biaya diperkirakan Guyon dan Simoragkir 2002.

\section{KESIMPULAN}

1. Pendapatan masyarakat. Karena dari hasil mata pencarian tersebut yang akan mencukupi kebutuhan mereka.

2. Nilai jual Sereh wangi (sebelum kebakaran Sereh wangi) perpanen yang memberikan kontribusi terbesar terhadap pendapatan masyarakat adalah dari tanaman nilai ekonomi sebesar Rp 201.680.000

3. pendapatan responden dari pemanfaatan masyrakat dari Sereh wangi dan sebaliknya pendapatan masyarakat (Sesudah Kebakaran Sereh wangi jugak meningkat mencapai Rp 63.601.811 sementara pendapatan responden dari hasil Sereh wangi

4. Pendapatan dari hasil pemanfaatan Sereh wangi memberikan hasil yang lebih besar dibandingkan dengan pendapatan dari sebelum terjadi kebakaranSereh wangi

\section{DAFTAR PUSTAKA}

Akbar, A. 2008. Pengendalian Kebakaran Hutan Berbasis Masyarakat Sebagai Suatu Upaya Mengatasi Risiko dalam REDD (Community-based Fire Management as an Effort to Solve the REDD Risk). Tekno Hutan Tanaman. Vol.1 (1): $11-22$.

Ayu, Helen. Yuseva., Rommy. Qurniati., Rudi. Hilmanto. 2014. Analisis finansial dan komposisi tanaman dalam rangka persiapan pengajuan izin HKm. Jurnal Sylva Lestari.

Barber, C.V dan Schweithelm, J. 2000. Trial by fire: forest fires and forestry policy in Indonesias era of crisis and reform. World Resources Institute. Washington. 76 hal.

Bowen, M.,R. Bompard, J.,M.Anderson, I.,P. Guizol, P. Gouyon, A. 2001. Anthropogenic firesin Indonesia: a view from Sumatra. Dalam Peter, E., Radojevic, M. (Eds.),

Daswir dan Kusuma, I. 2006. Pengembangan Tanaman Sereh Wangi di SawahluntoSumate ra Barat. Bulletin Penelitian Tanaman Rempah dan Obat. 18(1) : 12-22. 